\title{
INTERESTS PROTECTED UNDER THE POLISH LAW ON COMBATING UNFAIR COMPETITION
}

\section{INTRODUCTION}

The Polish law on combating unfair competition is currently governed by two underlying laws: the Act of 16 April 1993 on Combating Unfair Competition (Ustawa o zwalczania nieuczciwej konkurencji, hereinafter referred to as $\mathrm{CUC}^{1}$ ), and the Act of 23 August 2007 on Combating Unfair Market Practices (Ustawa o przeciwdziałaniu nieuczciwym praktykom rynkowym, hereinafter referred to as $\mathrm{CUMP}^{2}$ ). Both acts coexist, although it is not easy to separate their objective ${ }^{3}$ and subjective ${ }^{4}$ scope. The assumption that CUMP is limited only to relations between entrepreneurs and consumers (business to consumer relations - B2C) and CUC to relations between entrepreneurs (business to business relations - B2B) is overly simplified. Such a distinction is difficult to make because certain market behaviours, regardless of whether the relationship is $\mathrm{B} 2 \mathrm{C}$ or $\mathrm{B} 2 \mathrm{~B}$, will simultaneously affect the interests of various market players. The assumption that CUC protects the interests of entrepreneurs and that CUMP protects the interests of consumers would be wrong.

The purpose of this paper is to indicate that both laws are aimed at protecting the same interests. The criteria of protected interests, rather than the relation (B2C and $\mathrm{B} 2 \mathrm{~B}$ ), should be decisive and taken into consideration in further reforms of Polish law on unfair competition.

\section{THE ACT OF 1926 ON COMBATING UNFAIR COMPETITION}

Traditionally, the provisions relating to the prevention and combating of unfair competition were contained in one single act. Originally, it was the Act of 2 August 1926 on Combating Unfair Competition (hereinafter referred to

\footnotetext{
1 Consolidated text, Dz. U. [Journal of Laws, JL] 2018, item 419.

2 Consolidated text, JL 2017, item 2070.

3 Namysłowska (2007): 1287.

${ }^{4}$ Giesen (2014): 34-38.
} 
as CUC19265), CUC 1926 was the first Polish Act on combating unfair competition, and it remained in force until 1939. After the war, due to the disappearance of competition between nationalized entities in Poland, CUC 1926 was not used, although it was still binding until 1993, when it became finally abolished and replaced by CUC.

The adoption of the Act of 1926 was preceded by a draft of the Act on the Rights on Enterprises and on Combating Unfair Competition prepared by Fryderyk Zoll, ${ }^{6}$ who stated that it was to be 'a full realization of the civilistic approach to the fight against unfair competition - an approach based on the recognition of the entrepreneur's objective right.' In the assumptions of the founders of CUC 1926, its main objective was to prevent acts of unfair competition (dishonesty of competition) directed against entrepreneurs. As emphasized in the literature, 'a vigorous, strong and comprehensive repression of unfair competition should become one of our primary tasks. ${ }^{77}$ It was also explained that an act of unfair competition takes place when "the competitiveness exceeds the boundaries outlined by the general interest and violates economic freedom and the interests of other individuals, using methods contrary to good manners adopted in a given environment. ${ }^{8}$ As a result, in order to safeguard against unfair competition, protection was granted to entrepreneurs whose rights to the enterprise (its attractive power) were infringed by the actions of another entrepreneur (a competitor). The criminal protection provided for in the Act was of an auxiliary nature and was also considered as a form of (auxiliary) consumer protection.

At the beginning, the pre-war legislator was concerned only with the interests of entrepreneurs operating on the market, whereas neither the interest of the client nor the interest of the consumer was taken into account. ${ }^{9}$ However, as early as the 1930 s, there were already views expressed in German law that law concerning unfair competition was not only to protect the particular interest of the entrepreneur, but also to play a social role and protect fair competition as a good in itself. Giving the entrepreneur a central role would be contrary to the essence of competition, since its protection is also in the interest of other participants in commercial life. ${ }^{10}$ The same trend was observed in Polish law. Thus already in CUC 1926 the need to protect the consumer was recognized and the consumer's interest was identified with the public interest. The drafters of the 1926 Act strove to ensure that the adopted solutions would lead to fair competition and, consequently, also affect the entire economic turnover, and thus also the situation of the consumer. Along with the development (in the second half of the twentieth century) of the law on combating unfair competition, it was assumed that

\footnotetext{
5 JL 1926, No. 9, item 559.

${ }^{6}$ Mayzel (1926b): 339-345.

7 Kraus, Zoll (1929): 16.

8 Dauman (1937): 153. Also: Mayzel (1926b): 339.

9 Szydło (2016): 31.

${ }^{10}$ Giesen (2014): 35-36 and the literature cited there.
} 
the aim of the regulation was not only to protect the entrepreneur, but also the consumer and the general public. ${ }^{11}$

On the other hand, however, on the grounds of CUC 1926 only an entrepreneur had a right of action. According to Article 1 sec. 2 and 3 of CUC 1926, in a situation of an infringement of rights, the harmed entrepreneur could demand that the offender refrain from acts that are harmful, remove the grounds that could cause confusion amongst recipients, return the unjust enrichment, as well as compensate and repair the damage in the event of bad intention or obvious negligence. However, the literature argued that, exceptionally, in the situation described in Article 4 of CUC 1926 (referring to geographical indications), collective legitimacy (actio popularis) was permissible. Claims for protection could be raised by manufacturers producing goods, their joint representation (if they had legal capacity) and any entrepreneur selling the products in question. ${ }^{12}$

\section{THE ACT OF 1993 ON COMBATING UNFAIR COMPETITION}

\section{Fair competition}

Already in the draft from $1992^{13}$ of CUC it was proposed that the new act should regulate the prevention and combating of unfair competition in the public interest, the interest of entrepreneurs and the interest of customers, especially consumers. The above proposal was accepted without changes in the adopted text of the Act of 1993.

From the Explanatory Memorandum of the draft of CUC it follows that the legislator's objective was to secure the existence of fair competition as a principle governing the economy, as well as to ensure fairness of competition. When drafting the Act, the Polish legislator took into account: the public interest, the interest of entrepreneurs and the interest of customers, including consumers. The Act was intended to eliminate unfair practices in business activity which lead to its deformation and falsification. The proposed solution expressed the 'thought of the versatility of the proposed regulation by taking into account the interests of the general public, entrepreneurs and consumers. This means that the infringement of each of the interests mentioned above has the same significance for the assessment of an activity as an act of unfair competition.' ${ }^{14}$

11 Szwaja, Kubiak-Cyrul (2019): 81-82.

12 Kraus, F. Zoll (1929): 128, 232-235.

${ }^{13}$ The Explanatory Memorandum of the CUC draft, Parliamentary printing (Druk sejmowy) of 18.05.1992, no. 278 Available on: <biblioteka.sejm.gov.pl> (hereinafter referred to as the Explanatory Memorandum of the CUC draft).

14 The Explanatory Memorandum of the CUC draft: 3. 


\section{Public interest}

One of objectives of CUC, set out in the first place, is the protection of the public interest. And although the notion of public interest is not defined in the Act, it should be understood as the interest of the whole society and community, and not the interest of individuals or a specific group of entities (entrepreneurs, customers, consumers). It is argued that the public interest "consists in maintaining competition as one of the "flywheels" of the economy and in its proper and effective functioning, as well as in compliance with the law, fair and undistorted functioning. ${ }^{15}$ This interest must be understood broadly as 'the interest of many unidentified entities genuinely affected by the behaviour of the wrongdoer. ${ }^{16}$ The Polish Supreme Court (Sąd Najwyższy) argued that a breach of public interest occurs 'when the effects of certain actions are common, affecting all potential entities on a given market, and not only a strictly defined group of them. The public interest is infringed when the prohibited activities limit the proper conditions for the functioning of the market, ensuring the possibility of the emergence and development of competition understood as a phenomenon characterizing the functioning of the economy.' ${ }^{17}$

Therefore, the public interest should be identified as contributing to the development of an overall economy based on legitimate competition and mutual fairness. One must agree with the position expressed in the literature that the public interest is intertwined with the interest of other market participants. When assessing the interests of the entrepreneur and the interests of the client, the public interest should also be taken into account..$^{18}$ It would even be possible to support the view that in a situation where it is necessary to resolve the conflict between the interests of entrepreneurs or clients and the public interest, the public interest should be of decisive importance. Theoretically, it could happen that certain actions, although they would infringe the interest of an entrepreneur or client, may be classified as acceptable precisely for reasons of protection of the public interest.

It should be added that CUC as such does not provide any special measures to protect the public interest. The public interest is mainly protected by the Act of 16 February 2007 on Competition and Consumer Protection (hereinafter referred to as CCP). ${ }^{19}$

${ }^{15}$ Szwaja, Kubiak-Cyrul (2019): 90.

${ }^{16}$ Sieradzka (2016): 51.

17 The judgment of the Polish Supreme Court of 20 April 2017 (III SK 21/16), Legalis.

18 Tischner (2014): 100.

${ }_{19}$ Consolidated text, JL 2019, item 369. According to Article 1 sec. 2 this Act provides for the principles and procedures applied to counteract competition-restricting practices, practices infringing collective consumer interests, use of abusive clauses in standard agreements, and anti-competitive concentrations of undertakings and their associations, where such practices, the use of abusive clauses or concentrations have or may have effects in the Republic of Poland. 


\section{Interest of entrepreneurs}

According to Article 2 CUC, entrepreneurs are natural and legal persons and organizational units without legal personality, which, by performing commercial or professional activity (even if only on the side), participate in economic activity. This definition should be understood autonomously and may be interpreted differently from the notion of an entrepreneur referred to in other acts. This will particularly apply to the definition of an 'entrepreneur' contained in Article 4(1) CCP, as well as in Article 2(1) CUMP.

In the Explanatory Memorandum of the CUC draft, it was emphasized that the act deliberately avoids using the term 'economic entity', and instead uses the term 'entrepreneur'. The aim here is to determine that the Act does not refer only to 'economic entities within the meaning of the Act on Commercial Activity, ${ }^{20}$ but also to all persons and organizations that participate in economic trade by conducting economic or professional activity. ${ }^{21}$ It is worth mentioning that running a business does not have to be the main goal of an entrepreneur, it is sufficient that the business activity is run on the side and does not have to be run for profit. The concept of conducting economic activity is also broadly defined: according to Article 1 CUC, it covers all industrial and agricultural production, construction, trade and services. The Act also applies to so-called freelance professions, to the extent that their representatives themselves, or as companies, engage in economic activity as entrepreneurs.

CUC refers to all Polish entities conducting business activity, as well as foreign natural and legal persons (Article 4 CUC), who benefit from the rights resulting from the provisions of the Act pursuant to international agreements binding the Republic of Poland or on the basis of the principle of reciprocity. There is no doubt that foreign entities conducting business activity on the territory of Poland must comply with the principles of fair competition.

\section{Interest of clients (and consumers)}

CUC also protects the interest of clients, although it does not define the concept of 'client.' The notion of a client is defined not only in Article 1 CUC, but also in Articles 5, 6, 10, 12, 13, 15 and 16, which in particular cover torts of unfair competition, and in Articles 24 and 25 on prohibited acts. The notion of a client should be understood broadly. A client may be not only a consumer as defined in Article $22^{1}$ of the Polish Civil Code of 23 April 1964 (hereinafter referred to as the $\mathrm{CC}^{22}$ ), and thus a natural person who performs a legal transaction with an entrepreneur not directly related to their business or professional activity. It can also be another entrepreneur purchasing the means

20 Act of 23 December 1988 on Commercial Activity (Ustawa o działalności gospodarczej, JL 1988, No. 41, item 324). The Act was repealed in connection with the entry into force of the Commercial Activity Law (Prawo działalności gospodarczej) of 19 November 1999, JL No. 101, item 1178.

21 The Explanatory Memorandum of the CUC draft: 4.

22 Consolidated version JL 2019, item 1145. 
of production or services or goods for resale (an indirect purchaser), as well as entities that are final recipients, which cannot be classified in any of the previous categories, such as associations, schools, courts, hospitals, offices. A client within the meaning of CUC is any market participant to whom the activities of other trade participants (entrepreneurs), offering different goods or services, are addressed, regardless of whether the client is an entrepreneur or a consumer. The decisive factor is that they are a client of the entrepreneur.

The amendment of 2007 of Article 1 CUC, whereby the phrase 'especially consumers' was repealed, did not constitute a change in the scope of CUC regulation. This action has an impact on the CUC's interpretation that the consumer's interest is not worthy of special emphasis, since it is protected on an equal level with the interests of all other clients. Moreover, the position that the protection of consumer interests is outside the scope of CUC is not justified. Consumers are not protected as a weaker, more vulnerable group of market participants, ${ }^{23}$ but they are protected as any other clients - a contracting party of an entrepreneur. The interests of the customer are placed on an equal level with the interests of the trader and the public interest. ${ }^{24}$ Article 1 of CUC makes no distinction in this respect.

There may be doubts, in connection with the amendment of Article 1 CUC and the entry into force of CUMP in 2007, as to whether it is possible to refer on the grounds of CUC to the model of an 'average consumer' which was developed in the jurisprudence of the Court of Justice the European Union (CJEU) and is currently defined in CUMP. According to Article 2 sec. 8 CUMP, an 'average consumer' means 'a consumer who is reasonably well informed, observant and circumspect; the assessment is made taking into account social, cultural, linguistic and cultural factors, and the consumer's belonging to a particular group of consumer's, understood as a clearly identifiable group of consumers who are particularly vulnerable to the impact of the market practice or to the product to which the market practice relates because of particular characteristics such as age, or physical or mental disability. ${ }^{25}$

Although it does not result from the content of CUC itself, I believe that actions that may threaten or violate the interest of the client-consumer should be assessed from the perspective of the average consumer. It is also undisputed in the literature that when assessing whether a given behaviour could be misleading (Articles 5, 6, 10,13, 16 CUC) or otherwise influence the consumer's decision (Articles 12, 15, 16 and 17a CUC), one should refer to the model

${ }^{23}$ A consumer treated as a vulnerable party in need of special protection is identified under CUC, CUMP and CC.

${ }^{24}$ Tischner (2014): 104.

${ }^{25}$ The adoption of such a model is in the view of the EU legislator, in line with the principle of proportionality and aims at enabling the effective application of the remedies contained in Directive 2005/29/EC of the European Parliament and of the Council of 11 May 2005 concerning unfair business-to-consumer commercial practices in the internal market and amending Council Directive 84/450/EEC, Directives 97/7/EC, 98/27/EC and 2002/65/EC of the European Parliament and of the Council and Regulation (EC) No 2006/2004 of the European Parliament and of the Council ('Unfair Commercial Practices Directive'), OJ L 149, 11.6.2005: 22-39. 
of an average consumer. ${ }^{26}$ At the same time, it does not seem justified that the model of an average consumer should be applied to the client-entrepreneur.

It is sufficient that only the customer's interest is threatened or violated for any action to be qualified as an act of unfair competition. Article 3 CUC regulates that an act of unfair competition is an act or omission that threatens or infringes the interest of another entrepreneur or customer. In this regard, it is not necessary for the application of Article 3 CUC to threaten or infringe the interest of another entrepreneur. It is enough that the interest of the client is threatened or infringed. In such a situation, however, the issue of active court legitimacy remains valid.

Although CUC aims at preventing and combating unfair competition in the interest of public, entrepreneurs and clients, currently only entrepreneurs, and to some extent also a national or regional organization whose statutory aim is to protect the interests of entrepreneurs, have active court legitimacy. Such a possibility does not exist for a natural person who is not an entrepreneur, and thus neither does it exist for a consumer. In the justification of the CUC draft, it was stressed that only the entrepreneur is actively entitled to take legal action, and the Act does not provide for actio popularis. A single client-consumer has no court legitimacy. The consumer may exercise their rights on the basis of other legal regulations. In a case where the infringement of an individual customer's interest constitutes a manifestation of unlawful activity to a greater extent, the active court legitimacy may be held by a consumer organization. ${ }^{27}$

\section{THE 2007 ACT ON COMBATING UNFAIR MARKET PRACTICES}

The purpose of CUMP was to implement into the Polish legal system Directive 2005/29 on unfair commercial practices. The implemented directive is based on the model of 'full harmonisation' which has affected the way it has been transposed into national legislation ${ }^{28}$. Full harmoniztation means that Member States had to adopt the provisions contained in the Directive in a strict manner. They may not introduce rules that are stricter than those set in the directive ${ }^{29}$.

${ }^{26}$ Szwaja, Kubiak-Cyrul (2019): 92, Tischner (2014): 104.

${ }^{27}$ Justification of the draft of CUC: 7.

${ }^{28}$ Szwaja, Tischner (2007): 1117; Kukiel-Kryńska (2007): 989.

${ }_{29}$ 'It is important to distinguish between minimum and maximum (or full) harmonisation requirements in directives. In the case of minimum harmonisation, a directive sets minimum standards, often in recognition of the fact that the legal systems in some EU countries have already set higher standards. In this case, EU countries have the right to set higher standards than those set in the directive.' More at: <https://eur-lex.europa.eu/legal-content/EN/ALL/?uri=uriserv\%3Al14527> [accessed 27 March 2020]. 
According to Article 1 CUMP, the Act defines the rules of combating unfair market practices in the interest of consumers and the public.

\section{The interests of consumers}

The provisions of CUMP protect the interests of the consumer. Pursuant to Article 2(2), the term 'consumer' should be understood as a consumer within the meaning of Article $22^{1} \mathrm{CC}$. According to the drafters of the Code, the reference to the Civil Code was proposed to achieve systemic compliance..$^{30}$ This argument seems to be justified. The reference to Article $22^{1} \mathrm{CC}$ is also contained in other acts, including Article 4(12) CUC. It is assumed in the literature that the term 'consumer' should be understood identically with respect to the CC, CUC and CUMP. ${ }^{31}$

The consequence of such an assumption is the necessity to apply the same interpretation of this term on the grounds of the CC and CUMP. However, the problem is that CUMP refers to different types of market practices which are defined in its Article 2(4). Therefore, there is a justified doubt as to whether the acts of law (or legal transactions - czynność prawna) ${ }^{32}$ involving a consumer and an entrepreneur within the meaning of Article 22(1) CC are the same as the market practices defined in CUMP. In fact, CUMP refers to a broader set of activities: any unfair market practices, and not only to legal transactions involving a consumer and an entrepreneur. It is reasonable to claim that CUMP concerns any activities (including factual activities - czynnośc faktyczna) conducted by the consumer in relation to the product offered by the entrepreneur. It is therefore proposed that the interpretation of CUMP, which must be in accordance with Directive 2005/29, should overlook the limitation laid down in Article $22^{1}$ CC. Thus, CUMP would not be limited to situations where a consumer takes legal actions against an entrepreneur. On the other hand, it is argued that such an interpretation is contra legem because if the wording of the provision is unequivocal there are no grounds for applying an interpretation in accordance with the EU Law. ${ }^{33}$

Article 1 of Directive 2005/29 imposes that the protection concerns only the economic interests of the consumer. This assumption is also reflected in recital 7 of the preamble to Directive 2005/29, which states that the Directive 'addresses commercial practices directly related to influencing consumers' transactional decisions in relation to products. It does not address commer-

30 See Parliamentary printing (Druk sejmowy) 1682, Government bill on combating unfair market practices. Available at: <http://orka.sejm.gov.pl/proc5.nsf/opisy/1682.htm> (hereinafter referred to as the Explanatory Memorandum of the CUMP draft).

31 Szwaja, Kubiak-Cyrul (2019): 92. There were also some opinions that the reference in the CUMP to Article 22(1) CC is inappropriate, because such a definition of 'consumer' is defective in the CUMP. See Tischner (2012): 126.

32 The CC does not provide any definition of acts of law (legal transactions). It is generally understood to be a complex legal event (zdarzenie prawne) in which the only necessary, or required element is a declaration of intent. Kępiński (2011): 412.

33 Tischner (2012): 126. 
cial practices carried out primarily for other purposes, including, for example, commercial communication aimed at investors, such as annual reports and corporate promotional literature. It does not address legal requirements related to taste and decency which vary widely among the Member States.'

Also in the Guidance for the application of Directive 2005/29, the European Commission states that this Directive does not refer to national provisions aimed at protecting non-economic interests. The Directive does not cover national rules on protecting human dignity, preventing sexual, racial and religious discrimination or on the depiction of nudity, violence and antisocial behaviour. ${ }^{34}$

Although it is not explicitly mentioned in Article 1 CUMP that it concerns only the economic interests of consumers, it should be assumed that only such interests are at stake in accordance with the assumptions underlying Directive 2005/29. This is further reflected in Article 4, according to which a practice is unfair when it distorts or may distort 'the market behaviour of the average consumer.' Such an understanding of consumer interests is consistent not only with Directive 2005/29 but also with CUC. It is also stressed in the literature that CUC concerns only the protection of the economic interests of participants in economic trade..$^{35}$

\section{Public interest}

While some authors argue that in CUMP the consumer interest plays the primary (priority) role, and that the public interest should be taken into account only in the second place, ${ }^{36}$ in my opinion such a view is not justified in the construction of the Act itself. Both the interest of consumers and the public interest should be equally protected.

It should be noted that the public interest, although mentioned in Article 1 CUMP, was not mentioned explicitly in Article 1 of Directive 2005/29. ${ }^{37}$ Article 1 of the Directive merely states that one of its objectives is also to 'contribute to the proper functioning of the internal market.' Therefore, Robert Stefanicki argues that, despite the omission of the term 'public interest' in Directive 2005/29, its objectives and those of CUMP are consistent. ${ }^{38}$ Such a position is also confirmed by the Explanatory Memorandum of the CUMP draft. This states that the public interest should be understood as 'ensuring fair and undistorted competition by protecting the overriding interest of the weaker market participants - consumers. ${ }^{39}$ However, in my opinion this interpretation is too narrow, because the public interest should not be perceived only from the point of view of the consumer. The reference in CUMP to the notion of 'public interest' allows the

${ }_{34}$ See Guidance on the Implementation/Application of Directive 2005/29/EC on Unfair Commercial Practices, COM(2016)320 final: 10.

35 Szwaja, Kubiak-Cyrul (2019): 87.

36 Michalak (2018): 49.

${ }^{37}$ However, the notion of public interest was mentioned in recital 5 of the preamble and in Article 11(2) of Directive 2005/29.

38 Stefanicki (2009): 97-98.

39 Explanatory Memorandum of the CUMP draft: 15. 
assumption that the public interest under both Acts (CUMP and CUC) should be interpreted in the same way. The common goal of both legal acts is to ensure fair and undistorted competition, which entails the protection of the interests of all market participants.

\section{The interests of entrepreneurs}

In CUMP, however, the interests of an entrepreneur are not mentioned, as is the case in CUC. Nevertheless, it should be assumed that the interest of an entrepreneur is also indirectly protected in CUMP through the protection of the public interest. One of the components of public interest is the interests of the entrepreneur. ${ }^{40}$

\section{CONCLUSIONS}

1. Polish law on combating of unfair competition has its roots in CUC 1926. At the time of its adoption the Act was modern and frequently applied. CUC 1926 referred to the relations between entrepreneurs, and its main objective was to protect the interests of entrepreneurs. However, it was noted that delicts of unfair competition may turn against consumers as well.

The Act of 1993 (CUC) provides for the protection of the public interest, the interest of entrepreneurs and that of clients. These interests are intertwined and cannot be separated. It is not appropriate to consider that one of these interests should be given priority. Despite this assumption, only the entrepreneur has an active court legitimacy. In the event of a breach of consumer interests, the consumer would not be entitled to raise claims under CUC

At the same time, the main beneficiary of CUMP is to be the consumer, who is the weaker party participating in the market turnover. This Act is also intended to protect the public interest. The interests of entrepreneurs will also be protected indirectly through the protection of public interest. The Acts cannot be treated separately and independently. The primary goal of both Acts is to guarantee fair competition. However, each Act puts different emphasis on securing the interests of certain market participants, which is reflected primarily in granting active court legitimacy only to some entities.

2. Directive 2005/29 introduced a separation of the protection of consumer interests in relation to entrepreneurs (B2C) and the protection of the interests of entrepreneurs in relation to entrepreneurs (B2B). This separation was not recognised in Polish law on combating unfair competition, which was based on the model of integrated protection. Basically CUC protects the public interest, the interests of entrepreneurs and the interests of clients, including consumers. These interests are, as a rule, interrelated and cannot be separated.

${ }^{40}$ Michalak (2008): 49. 
CUC refers to acts of unfair competition, which concerned both, the relations between entrepreneurs (B2B) and the relations between an entrepreneur and a consumer (B2C). A characteristic example of the latter is Article 17a CUC. Undoubtedly, also other delicts (torts), mentioned in Article 10 or Article 13 CUC, for example, refer to relations with consumers, too.

Since Directive 2005/29 covers only B2C relations, the problem arises of whether it is possible to draw a clear distinction between such practices and $\mathrm{B} 2 \mathrm{~B}$ practices. Only theoretically is such a distinction easy to make, but in practice it is more difficult to draw a line between unfair market practices and acts of unfair competition. This is because the relationship between the interests of all market participants is like a vessel. The injury of the interest of the one of the market participants has consequences that can be felt by the other participants.

Looking back, the implementation of Directive 2005/29 has proved to be flawed in many respects. The method of implementation, which aimed to separate the scopes of both legislative acts in regard to $\mathrm{B} 2 \mathrm{~B}$ and $\mathrm{B} 2 \mathrm{C}$ relations in the model of integrated protection, is practically impossible to follow. A full adoption of this method would mean a break with the existing concepts, the acquis of the judicature and jurisprudence established on the basis of the Act on combating unfair competition.

3. Taking into account all the circumstances set out above, the best solution would be to adopt a new legislative act which would combine the provisions of both earlier acts (CUC and CUMP). The adoption of a single legislative act aimed at ensuring fairness in trade would also require rethinking the way in which the Directive should be implemented. On the other hand, I also believe that the solutions adopted in CUC should not be abandoned. The Act proved to be an effective guarantor of fairness in trade.

Jakub Kepiński

Adam Mickiewicz University, Poznań

jakep@amu.edu.pl

https://orcid.org/0000-0002-3738-1818

Dauman, J. (1937). O „nieuczciwej konkurencji” de lege ferenda. Miesięcznik Prawa Handlowego i Wekslowego 5/8: 152-155.

Giesen, B. (2014). Przedmiot ochrony przewidzianej ustawą o zwalczaniu nieuczciwej konkurencji. Monitor Prawniczy 6: 34-38.

Kępiński, M. (2011). Civil Law. General Part, [in:] W. Dajczak, A.J. Szwarc, P. Wiliński (eds.), Handbook of Polish Law. Warsaw: 403-420.

Kraus, A., Zoll, F. (1929). Polska ustawa o zwalczaniu nieuczciwej konkurencji z objaśnieniami dra Alfreda Krausa i dra Fryderyka Zolla. Poznań.

Kukiel-Kryńska, A. (2007). Implementacja dyrektyw opartych na zasadzie harmonizacji pełnej na przykładzie dyrektywy o nieuczciwych praktykach rynkowych. Monitor Prawniczy 18: 989-994.

Mayzel, M. (1926a). O zwalczaniu nieuczciwej konkurencji. Przegląd Prawa Handlowego 5: 193-201.

Mayzel, M. (1926b). O zwalczaniu nieuczciwej konkurencji (Dokończenie). Przegląd Prawa Handlowego 8: 339-345. 
Miąsik, D. (2014). Objaśnienie do art. 24, [in:] T. Skoczny (ed.), Ustawa o ochronie konkurencji i konsumentów. Komentarz [Online]. Legalis. Warsaw.

Michalak, A. (2008). Przeciwdziałanie nieuczciwym praktykom rynkowym. Komentarz. Warsaw.

Namysłowska, M. (2007). Nowa ustawa o przeciwdziałaniu nieuczciwym praktykom rynkowym. Monitor Prawniczy 23: 1287-1292.

Namysłowska, M. (2014). Czarna lista nieuczciwych praktyk handlowych a granice prawa zwalczania nieuczciwej konkurencji w Unii Europejskiej. Analiza prawnoporównawcza. Warsaw.

Sieradzka, M. (2008). Ustawa o przeciwdziałaniu nieuczciwym praktykom rynkowym. Komentarz. Warsaw.

Sieradzka, M. (2016). Objaśnienie do art. 1, [in:] M. Zdyb, M. Sieradzka (eds.), Ustawa o zwalczaniu nieuczciwej konkurencji. Komentarz. Warsaw: 35-63.

Stefanicki, R. (2009). Ustawa o przeciwdziałaniu nieuczciwym praktykom rynkowym. Komentarz. Warsaw.

Szwaja, J., Tischner, A. (2007). Implementacja dyrektywy 2005/29/WE o zwalczaniu nieuczciwych praktyk handlowych do prawa polskiego. Monitor Prawniczy 20: 1117-1122.

Szwaja, J., Tischner, A. (2014). Odpowiedzialność cywilnoprawna za czyny nieuczciwej konkurencji, [in:] M. Kępiński (ed.), System prawa prywatnego. Volume 15: Prawo konkurencji. Warsaw: 581-638.

Szwaja, J., Kubiak-Cyrul, A. (2019). Objaśnienie do art. 1, [in:] J. Szwaja (ed.), Ustawa o zwalczaniu nieuczciwej konkurencji. Komentarz. Warsaw: 78-100.

Szydło, M. (2016), Wprowadzenie, [in:] M. Zdyb, M. Sieradzka (eds.), Ustawa o zwalczaniu nieuczciwej konkurencji. Komentarz. Warsaw: 27-34.

Targosz, T. (2012). Ustawa o przeciwdziałaniu nieuczciwym praktykom rynkowym - model ochrony, zasady, zakres ochrony, implikacje dla systemu prawa konkurencji i konsumentów, [in:] E. Nowińska, D. Kasprzycki (eds.), Nieuczciwe praktyki rynkowe. Ocena regulacji. Cracow: $29-52$.

Tischner, A. (2012). Pojęcie „przeciętny konsument” w ustawie o przeciwdziałaniu nieuczciwym praktykom rynkowym na tle prawa i orzecznictwa Unii Europejskiej, [in:] E. Nowińska, D. Kasprzycki (eds.), Nieuczciwe praktyki rynkowe. Ocena regulacji). Cracow: 89-126.

Tischner, A. (2014). Cele i zakres zastosowanie ZNKU, [in:] M. Kępiński (ed.), System prawa prywatnego. Volume 15: Prawo konkurencji. Warsaw: 89-105.

\section{INTERESTS PROTECTED UNDER THE POLISH LAW ON COMBATING UNFAIR COMPETITION}

\section{Summary}

The article concerns the problem of determining the relationship between the Polish Act on Combating Unfair Competition of 1993 and the Polish Act on Combating Unfair Market Practices of 2007. The problem arose when the Unfair Commercial Practices Directive was implemented in the Polish system in 2007. The Directive is based on the division, which was not known in the Polish Act on Combating Unfair Competition, relating to business-to-business (B2B) and businessto-consumer (B2C) relationships. The adoption of such an artificial division has raised numerous problems of interpretation. A better solution would be to adopt in subsequent legislative works the criterion of protected interests, which are the basis of each of the analysed legal acts. Consequently, it will be necessary to introduce legislative changes to the Polish Law on Combating Unfair Competition.

Keywords: unfair competition; unfair commercial practices; combating of unfair competition; consumer; client entrepreneur; public interest 